\title{
KÖZÚTI ZAJ VÁLTOZÁSÁNAK ÉRTÉKELÉSE VÁROSI KÖRNYEZETBEN
}

\section{EVALUATION OF ROAD TRAFFIC NOISE CHANGES IN URBAN ENVIRONMENT}

\author{
Kocsis Dénes \\ Debreceni Egyetem, Müszaki Kar, Környezet- és Vegyészmérnöki Tanszék, Cím: \\ 4028 Magyarország, Debrecen, Ótemetö utca 2-4; Telefon: +3652/415155-77827; \\ kocsis.denes@eng.unideb.hu
}

\begin{abstract}
This work introduces possibilities for the evaluation of road traffic noise changes in urban environment. The investigation was carried out based on the current Hungarian legislation and CNOSSOS-EU methods, which was introduced to standardize the approach for environmental noise problems within the European Union. The calculations were executed for road sections with heavy traffic in the city of Debrecen. The traffic data derived from the database of the Hungarian Road Administration. The investigated period was from 1995 to 2015. In the case of the examined period the involved road segments' road traffic noise emission was changed significantly. There were intervals with considerable increases and decreases, and significant differences were found between the road segments.
\end{abstract}

Keywords: noise pollution, road traffic, CNOSSOS-EU

\section{Összefoglalás}

Jelen munka a közúti zaj városi környezetben történő változásának követésére és értékelésére irányuló lehetőségeket ismertet. Az értékelés a jelenleg hatályos magyar jogszabályi háttér, illetve a közelmúlt európai uniós egységesítési törekvései eredményeképpen megszülető CNOSSOS-EU metodikák segítségével történt. A számítások Debrecen város belterületén elhelyezkedő, forgalmas közúti szelvények esetében kerültek elvégzésre. A felhasznált forgalmi alapadatok a Magyar Közút Nonprofit Zrt. adatbázisából származnak. A vizsgálat 1995-2015 közötti időszakra vonatkozik. A munka eredményeképpen megállapítható, hogy a vizsgált időszakban az értékelésbe bevont szakaszok esetében jelentős változás következett be közúti zajkibocsátás szempontjából. Az évek során jelentős zajterhelés növekedést, illetve csökkenést tartalmazó intervallumok jelentkeztek, és az elemzett szakaszok között is lényeges eltérések adódtak.

Kulcsszavak: zajszennyezés, közúti forgalom, CNOSSOS-EU

\section{Bevezetés}

Napjainkra a környezeti zajterhelés világszerte az egyik legjelentősebb környezetvédelmi problémává vált. A 2014. évben elkészült Noise in Europe [1] jelentés szerint Európában évente 10000 esetben eredményez korai elhalálozást. Ezen felül jóval nagyobb számban is előfordulhatnak hosszútávon akár súlyos egészségkárosító következményekkel járó esetek. A jelentés éves szinten 900 000-re teszi a környezeti zaj okozta magas vérnyomás kialakulását, és 8 millióra azon felnőttek számát, akik a 
zajterhelés következtében alvászavartól szenvednek. A környezeti zaj növekvő jelentősége mellett figyelembe kell venni, hogy az újabb kutatások szerint egyre több egészségkárosító hatással hozható összefüggésbe [2].

A környezeti zaj forrásai közül ki kell emelni a közúti közlekedést, ugyanis ez bizonyul napjaink legdominánsabb forrásának [1]. A közúti zaj esetében is általánosan növekvő terhelést határoztak meg korábbi vizsgálatok [3]. Ez a növekvő terhelés azzal is együtt jár, hogy az éjszakai csendes időszakok hossza csökken [4]. Mindezek eredményeképpen az Egészségügyi Világszervezet (WHO) megállapítása szerint globálisan már 1 millió egészséges életév elvesztéséért felelős minden évben a közlekedési zaj, és hatását tekintve a második legjelentősebb környezeti szennyezésként határozták meg, közvetlenül a levegőszennyezés után [2].

$\mathrm{Az}$ Európai Unión belül a zaj okozta problémák átfogó, közös rendszerben történő kezelése a 2002/49/EC Environmental Noise Directive (END) [5] óta napirenden lévő kérdés. Ez az irányelv az unió tagországait adatszolgáltatásra kötelezi, de az utóbbi évek tapasztalatai alapján ezek felhasználása számos nehézségbe ütközött. Az Európai Unió látva azt, hogy a tagországai által biztosított zajadatok nem minden esetben vethetöek össze - tekintettel a tagországok sajátos nemzeti szabályozására - 2012-re közös megközelítési metódust dolgozott ki, amely CNOSSOS-EU (Common Noise Assessment Methods in Europe) néven ismert [6]. Ez elsősorban az európai zajtérképezési folyamatok és eredmények egységesítését célozta meg [7]. Ezen metodika segítségével végzett számítások esetén továbbra is kulcsfontosságú kérdés a megfelelő forgalmi adatok rendelkezésre állásának biztosítása [8], amelyek felhasználásával további paraméterek meghatározása mellett a közúti zajemisszió megbecsülhetö.

Jelen munka célja a városi közúti zaj változásának értékelése Debrecen város néhány nagy forgalmú, belterületi útszakaszának vizsgálatával. Az elemzéshez a jelenleg aktuális magyar szabályozás, és a közeljövőben a magyarországi rendszerbe is adaptálandó CNOSSOS-EU metodikák kerültek alkalmazásra. Célként került meghatározásra az 1995-2015 közötti intervallum teljes áttekintése a kiválasztott útszakaszokon.

\section{Alkalmazott módszerek}

A vizsgálatokhoz a Debrecen városán is áthaladó 4-es számú elsőrendủ főút belvároshoz legközelebbi, állandó forgalomszámlálási merőhellyel rendelkező szakasza (szelvény kód: 1039), valamint a 4-es fö́tból az említett szakaszt követően letérő és onnan induló 471-es másodrendü föút első részlete (kód: 3100) került kiválasztásra. $\mathrm{Az}$ útszakaszok általános adatai az 1. táblázatban láthatóak.

1. táblázat. $A$ vizsgált útszakaszok általános adatai a Magyar Közút Nonprofit Zrt. adatbázisa alapján [9]

\begin{tabular}{|c|c|c|}
\hline Szelvény kódja & 1039 & 3100 \\
\hline Közút száma & 4 & 471 \\
\hline Útkategória (föút) & I. rendü & II. rendü \\
\hline $\begin{array}{c}\text { Számlálóállomás } \\
\text { helyzete [km+m] }\end{array}$ & $225+883$ & $1+489$ \\
\hline $\begin{array}{c}\text { Szakasz kezdőpont } \\
{[\mathrm{km}+\mathrm{m}]}\end{array}$ & $225+524$ & $0+000$ \\
\hline $\begin{array}{c}\text { Szakasz végpont } \\
{[\mathrm{km}+\mathrm{m}]}\end{array}$ & $227+109$ & $1+570$ \\
\hline $\begin{array}{c}\text { Forgalmi sávok } \\
\text { száma }\end{array}$ & 4 & 2 \\
\hline
\end{tabular}

A forgalmi adatok az útkezelő 1995-től 2015-ig megjelent éves keresztmetszeti forgalomszámlálási eredményein alapulnak [9]. Az 1039-es kódú szelvény esetében a vizsgált időszakban miden évben méréssel történt a forgalomnagyság meghatározása 
(évenkénti átlagos számolt napok: 109,00 nap; szórása: 28,91 nap; minimuma: 33 nap; maximuma: 159 nap). Az 1996-tól ilyen néven szereplö 3100-as szelvény esetében 1996-tól kezdődően három nem számolt év volt (2006; 2008; 2009). A mért napok átlagos száma ez esetben alacsonyabb (évenkénti átlagos számolt napok: 19,25 nap; szórása: 17,71 nap; minimuma: 0 nap; maximuma: 81 nap), mint a 4-es fóúthoz tartozó szelvény esetében.

A vizsgált szakaszokra $\mathrm{L}_{\mathrm{Aeq}(7,5)}$ paraméterértékek kiszámítása történt a jelenleg hatályos magyar jogszabály szerint (25/2004. (XII. 20.) KvVM rendelet a stratégiai zajtérképek, valamint az intézkedési tervek készítésének részletes szabályairól). A megengedett sebesség 50 $\mathrm{km} / \mathrm{h}$, a kopóréteg akusztikai érdességi kategóriája minden esetben $\mathrm{B}$ (lásd a rendeletet) volt. A CNOSSOS-EU metodikája szerint $\mathrm{L}_{\mathrm{w}}$,eq,line paraméter is kiszámításra került, a megadott referenciaértékek alkalmazása mellett [6].

\section{Eredmények}

A közúti zaj számított értékeinek évenkénti változásáért a vizsgálat során minden esetben a forgalom mennyiségének és jellegének (az egyes akusztikai jármükategóriákhoz tartozó elhaladó jármüvek aránya) változása volt a felelős, tekintettel arra, hogy az összes többi paraméter a számításoknál állandó értéken szerepelt. $\mathrm{Az}$ 1. ábrán látható $\mathrm{az} \mathrm{L}_{\mathrm{Aeq}(7,5)}$ értékek évenkénti változása az értékelésbe bevont szelvények esetében. Általánosságban elmondható, hogy a kezdeti 2000-es évek elejéig tartó növekedést egy közel stagnáló, majd egy jelentősebb csökkenést hozó szakasz váltotta fel. Ennek okainak feltárása (pl. új utak átadása, forgalomszabályozás, üzemanyag árak, stb.) túlmutat jelen munka terjedelmén.

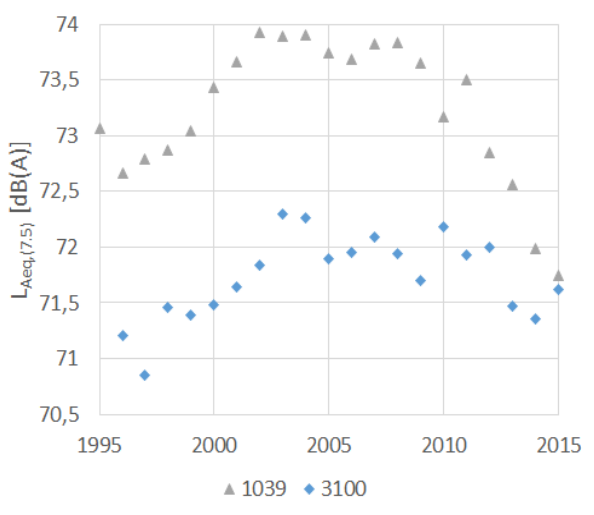

1. ábra. A nappali idöszakra (06-22 óra) vonatkozó $L_{A e q(7,5)}$ paraméterértékének változása 1995-2015 között a vizsgált két útszakasz esetében

$\mathrm{Az}$ éjszakai értékekre meghatározott alacsonyabb $\quad \mathrm{L}_{\text {Aeq(7,5) }} \quad$ eredmények ugyanolyan irányú változást mutatnak be a számítási módszerből adódóan. Ezek évenkénti alakulása látható a $\mathbf{2}$. ábrán.

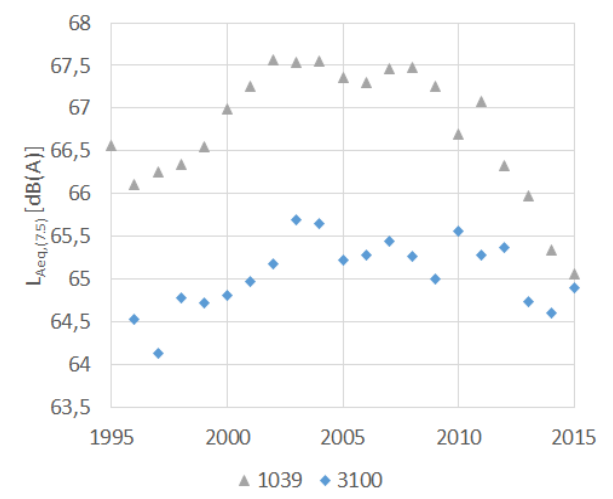

2. ábra. Az éjszakai időszakra (22-06 óra) vonatkozó $L_{A e q(7,5)}$ paraméterértékének változása 1995-2015 között a vizsgált két útszakasz esetében

A CNOSSOS-EU metodikája szerint

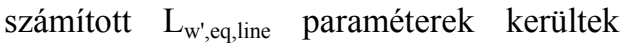
ábrázolásra a 3. ábrán. 


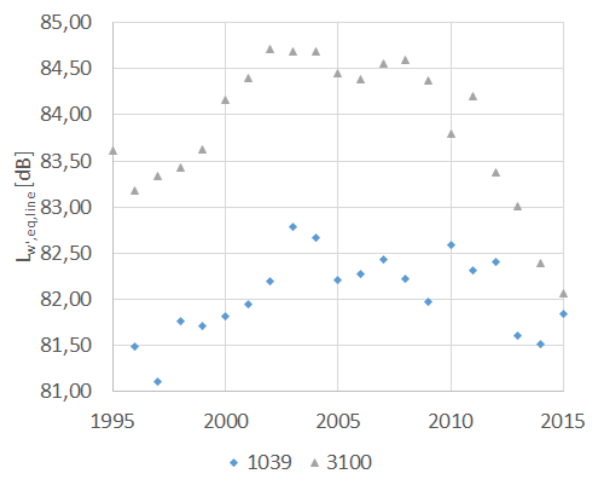

3. ábra. A CNOSSOS-EU metodikája alapján számitott $L_{w^{\prime}, \text { eq,line }} \quad$ paraméterek változása 1995-2015 között a vizsgált útszakaszok esetében

A CNOSSOS-EU számításhoz kapcsolódóan meg kell jegyezni, hogy a módszer által használt negyedik akusztikai jármükategórián (motorkerékpárok) belül megkülönböztet két alcsoportot motortérfogat szerint [6]. A két alcsoporthoz tartozó eloszlásokról a magyar adatbázisok nem tartalmaznak információt, jelen számításban 50-50\%-os aránnyal kerültek értékelésre. Mindenestre felhívja a figyelmet arra, hogy a magyarországi gyakorlat esetén forgalomszámlálási módosításokra lesz szükség az EU egységes megközelítésének adaptációjához.

\section{Következtetések}

Összességében elmondható, hogy a vizsgált szakaszok esetében jelentős változások történtek a közúti zaj tekintetében. Az értékelés mind a jelenleg hatályos magyar és az EU által fejlesztett metodika szerint megvalósult. Az eddigi kutatások rávilágítottak arra, hogy a közeljövő egyik fontos megoldandó feladata a két metodika összehangolása.

\section{Szakirodalmi hivatkozások}

[1] European Environment Agency, Noise in Europe 2014. Publications Office of the European Union, Luxembourg, Tech. Rep. 10/2014, 2014.

[2] Fritschi, L., Brown, L., Kim, R., Schwela, D., Kephalopolous, S., Burden of Disease from Environmental Noise: Quantification of Healthy Years Life Lost in Europe. World Health Organisation, 2011.

[3] Morley, D. W.,Gulliver, J., Methods to improve traffic flow and noise exposure estimation on minor roads. vol. 216, 2016. pp. 746-754.

[4] Hammer, M. S., Swinburn, T. K., Neitzel, R. L., Environmental noise pollution in the United States: developing an effective public health response. vol. 122, 2014. pp. 115.

[5] Directive 2002/49/EC of the European parliament and the Council of 25 June 2002 relating to the assessment and management of environmental noise. vol. 189, 2002.

[6] Kephalopoulos, S., Paviotti, M.,Ledee, F. A., Common noise assessment methods in Europe (CNOSSOS-EU). 2012. pp. 180.

[7] Kephalopoulos, S., Paviotti, M., AnfossoLédée, F., Van Maercke, D., Shilton, S., Jones, N., Advances in the development of common noise assessment methods in Europe: The CNOSSOS-EU framework for strategic environmental noise mapping. vol. 482, 2014. pp. 400-410,

[8] Morley, D., de Hoogh, K., Fecht, D., Fabbri, F., Bell, M., Goodman, P., Elliott, P., Hodgson, S., Hansell, A., Gulliver, J., International scale implementation of the CNOSSOS-EU road traffic noise prediction model for epidemiological studies. vol. 206, 2015. pp. 332-341,

[9] Magyar Közút Nonprofit Zrt, Az országos közutak 1995-2015. évre vonatkozó keresztmetszeti forgalma (évenkénti kiadás). 2015. 